\title{
BIOMARKERS RESPONSES IN FISH (Atherinella brasiliensis) OF PARANAGUÁ BAY, SOUTHERN BRAZIL, FOR ASSESSMENT OF POLLUTANT EFFECTS
}

\author{
Ciro Alberto de Oliveira Ribeiro ", Alberto Katsumiti, Patrícia França, Jocieli Maschio, \\ Eliandra Zandoná, Marta Margarete Cestari,Thainá Vicari, Hélène Roche, \\ Helena Cristina Silva de Assis and Francisco Filipak Neto
}

\author{
Universidade Federal do Paraná - Departamento de Biologia Celular
} (Caixa Postal 19031, Centro Politécnico 81531-980 Curitiba, PR, Brasil)

*Corresponding author: ciro@ufpr.br

\begin{abstract}
Paranaguá bay is a complex estuary located in southern Brazil containing three protected areas listed by UNESCO. Historically, the estuary has been affected by urban, industrial, agricultural and harbor activities, and occasional accidents. Specifically, the explosion of the Chilean ship Vicuña in December 2004 spilled methanol and crude and fuel oils which affected both protected and nonprotected areas. The present study sought to investigate the pollution threat to aquatic organisms in order to evaluate the potential effects of pollutants. One hundred and twenty adult fish Atherinella brasiliensis were collected from different sites within Paranaguá estuary, including the harbor and open ocean, during summer, autumn and winter of 2005. Among the biomarkers, the somatic index, chemical analysis of bile, biochemical, genetic and morphological parameters were considered. Chemical analysis of bile showed a continuous bioavailability of polycyclic aromatic hydrocarbons (PAHs) according to proximity to the harbor site. The histopathological findings have demonstrated aconsiderable incidence of severe pathologies in the liver and gills, corroborated by biochemical disturbances and genetic damage. These findings indicate that more studies are necessary to evaluate both water quality and fish health so as to permit a better analysis of the impact of pollution in Paranaguá estuary.
\end{abstract}

\section{RESUMO}

\begin{abstract}
A Baia de Paranaguá é um complexo estuarino localizado no sul do Brasil constituído de três áreas de proteção ambiental listadas pela UNESCO. Historicamente, o estuário tem sido afetado por atividade urbana, industrial, agricultura e portuária, e eventualmente por acidentes. Particularmente a explosão do navio Chileno Vicuña em dezembro de 2004 derramou metanol, óleo cru e combustível atingindo áreas protegidas e não protegidas. O presente estudo tem por objetivo investigar a poluição em organismos aquáticos. Cento e vinte indivíduos adultos do peixe Atherinella brasiliensis foram coletados em quatro diferentes pontos de coleta no estuário de Paranaguá, partindo do porto até o oceano aberto nos períodos de verão, inverno e primavera de 2005. Os índices somáticos, parâmetros químicos, enzimáticos, genéticos e morfológicos foram considerados. As análises histopatológicas demonstraram expressiva incidência de patologia no fígado e nas brânquias algumas vezes corroboradas pelas alterações bioquímicas. Danos genéticos e anormalidades genéticas também foram observados. As análises químicas na bile mostraram uma contínua biodisponibilidade de hidrocarbonetos policíclicos aromáticos para os organismos aquáticos. Os dados obtidos indicam que a qualidade da água e a saúde dos peixes encontram-se bastante comprometidos no estuário de Paranaguá.
\end{abstract}

Descriptors: Biomonitoring, Biomarkers, Aterinella brasiliensis, Paranaguá bay.

Descritores: Biomonitoramento, Biomarcadores, Aterinella brasiliensis, Baia de Paranaguá

\section{INTRODUCTION}

Paranaguá estuary is located in southern Brazil and presents a very important and complex ecosystem with protected areas listed by UNESCO. A considerable area of Paranaguá estuary is continuously impacted by urban, industrial, agricultural and harbor activities. In December 2004, the explosion of the Chilean ship Vicuña spilled methanol and crude and fuel oils over more than $30 \mathrm{~km}^{2}$ affecting protected areas, sea food farms, beaches and mangrove swamps, and thus contributing to the already existing problem of the human activities in the Paranaguá estuary (KATSUMITI et al., 2009). 
According to Vanparys et al. (2008) one of the important tasks of environmental risk assessment is the evaluation of the causal relationship between contaminants and their adverse health effects on the biological systems in the environment. In general, marine biota is exposed to a variety of contaminants, and biomarkers are useful to verify their biological effects and establish some of the aforementioned links. Viarengo et al (2007), for example, described the importance of biomarkers at different levels of biological organization in bio monitoring studies, and Pikkarainen (2006) reported that the necessity of monitoring biological effects has been recognized by several international programs and committees (HELCOM, 2006; ICES, 2001; UNEP, 1999).

Biomarkers may be derived from morphological, biochemical and physiological alterations in organisms on their exposure to xenobiotics, integrating biological responses to contamination and may thereby indicate sublethal exposure. According to Lyons et al. (2006) and Akaishi et al. (2007), the identification of increased incidence of disease and pathological conditions in aquatic organisms, whether caused by infectious agents, environmental factors or xenobiotics, is considered a highly relevant indicator of ecosystem health and potential risks to human populations (ALVES COSTA et al., 2007; DAMÁSIO et al., 2007; RABITTO et al., 2011).

Fish are particularly sensitive to the environmental contamination of water and, therefore, pollutants may significantly interfere with several of their biochemical processes. Hydrocarbons can activate ethoxyresorufin $O$-deethylase (EROD) detoxification mechanisms in fish (TEJEDA-VERA et al., 2008), while many pollutants change the redox milieu of cells, eliciting an antioxidant defense response or causing oxidative damage in cellular macromolecules of aquatic organisms, such as DNA (FILIPAK NETO et al., 2007; ANDRIGHETTIFRÖHNER et al., 2006). Histological endpoints are helpful tools for detecting and characterizing the biological effects of acute and chronic exposure to chemicals (MIRANDA et al., 2008; OLIVEIRA RIBEIRO et al., 2005b; SILVA et al., 2009; SILVA ET al., 2011; STENTIFORD et al., 2003; RABITTO et al., 2011), while somatic indexes are important to explain the effects of pollutants on growth, longevity and reproductive ability of organisms (ALBERTO et al., 2005; OLIVEIRA RIBEIRO et al., 2005b; TEJEDO-VERA et al., 2008).Hydrocarbon bioavailability depends on the type of oil and biological degradation and so the determination of metabolites of polycyclic aromatic hydrocarbons (PAHs) in the bile of fish is another recommended biomarker (OLIVEIRA RIBEIRO et al., 2005b).
Katsumiti et al. (2009) reported the effects of the acute impact of the Vicuña accident using Cathorops spixiias as bio indicator. According to the authors, caution is necessary when biomarkers are used to evaluate accidents in historically contaminated regions. As far as we know, the studies with Cathorops spixii reported by Katsumiti et al. (2009) and the current study with $A$. brasiliensis are the only ones on the impact of human activities in the Paranaguá estuary using fish as bio indicators.

The hypothesis defended here is that human activities in Paranaguá bay have compromised aquatic organisms' health chronically by deteriorating water quality and that the Vicuña accident contributed to this environmental degradation. To corroborate this hypothesis, the human impact in Paranaguá estuary was investigated using Atherinella brasiliensis as the sentinel species, and somatic, chemical, enzymatic, genetic and morphological parameters were evaluated.

\section{Material and Methods}

A total of one hundred and twenty adult fish Atherinella brasiliensis were caught at four sites (PI, PII, PIII and PIV) between February and October 2005, (summer, autumn and winter seasons; 10 fish per site and season) in Paranaguá estuary (25 $5^{\circ} 19^{\prime} 430^{\prime \prime}$ S, 48 32'398'W) (Fig. 1). The study sites were chosen along a pollution gradient extending from Paranaguá city (impacted by extensive urban and harbor activities; where the Vicuña exploded (PI)) out to Pontal do Sul (Paranaguá estuary; PIV; Figure 1). Fish were captured with nets and transported in boxes protected from light and temperature variations to the Ocean Studies Center of the Federal University of Parana. The journey took about $30 \mathrm{~min}$, and biological samples were obtained after fish acclimation under controlled conditions of aeration and temperature for 60 min.

The fish were anesthetized with benzocaine (200 ppm dissolved in water) and killed by spinal cord section after blood sampling, measurements of total length and weights then being recorded (Table 1). Axial muscle, liver, gills, blood and head kidney were sampled for biochemical, morphological and genetic analyses.

\section{Somatic Indexes}

Hepatosomatic (HSI) and gonad-somatic index (GSI), and Fulton's condition factor (K) were calculated as follows. HSI $=\left[\left(\mathrm{W}_{\text {liver }} / \mathrm{W}_{\text {fish }}\right)\right] \times 100$; GSI $=\left[\left(\mathrm{W}_{\text {gonad }} / \mathrm{W}_{\text {fish }}\right)\right] \times 100 ; \mathrm{K}=100 \times \mathrm{W}_{\text {fish }} / L^{3}$, where $\mathrm{W}$ is the weight (in g) and $L$ is the total length of the fish (in $\mathrm{cm}$ ). These indexes were transformed for statistical comparisons. 


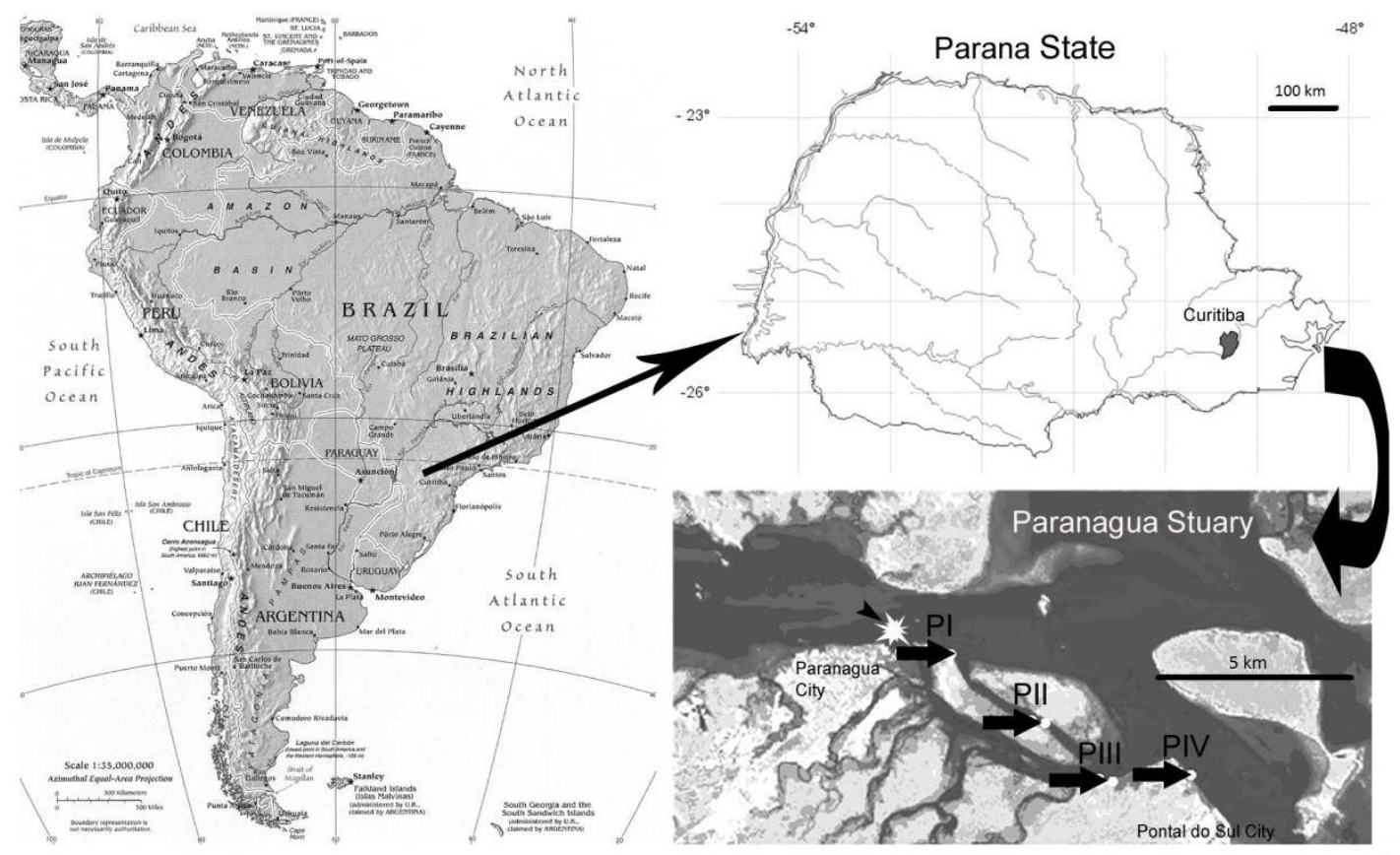

Fig. 1. Localization of the study sites (PI, PII, PIII and PIV) in Paranguá Bay, Southern Brazil.

Table 1. Comet assay of head kidney nuclei and nuclear alterations of erythrocytes of Atherinella brasiliensis collected from Paranaguá estuary in winter after Vicuña ship accident

\begin{tabular}{ccc}
\hline \hline & Cometassay & $\begin{array}{c}\text { Nuclear } \\
\text { alterations }\end{array}$ \\
\hline PI & $193.23 \pm 32.23^{\mathrm{a}}$ & $53.6 \pm 33.23^{\mathrm{a}}$ \\
PII & $241.14 \pm 44.78^{\mathrm{b}}$ & $38.5 \pm 23.58^{\mathrm{a}}$ \\
PIII & Notsampled & Notsampled \\
& $156.07 \pm 42.30^{\mathrm{c}}$ & $27.07 \pm 17.77^{\mathrm{b}}$ \\
\hline PIV & & \\
\hline
\end{tabular}

Different letters indicate statistically different groups

Chemical Analysis of Bile

Bile samples were diluted in methanol $48 \%$ (1:600) and PAHs were detected by fixed-wavelength fluorescence performed in the spectrofluorimeter (AAS et al., 2000; OLIVEIRA RIBEIRO et al., 2005a). The wavelength pairs of excitation/emission of 288/330 nm, 267/309 nm, 334/376 nm, 364/406 nm and $380 / 422 \mathrm{~nm}$ were used for the detection of naphthalene-type (2 rings), phenanthrene-type (3 rings), pyrene-type (4 rings), benzo(a)pyrene-type (5 rings), and benzo(ghi)perylene-type (6 rings) PAHs, respectively. The PAH concentrations were determined through comparison with a standard curve for each group of rings and normalized by protein content in bile (BRADFORD, 1976).

\section{Biochemical Procedures}

Liver and muscle samples were frozen and kept at $-70^{\circ} \mathrm{C}$ until analysis. Then samples were thawed on ice, homogenized in $0.1 \mathrm{M}$ potassium phosphate buffer $(\mathrm{pH} 7.5$ for muscle and $\mathrm{ph} 6.5$ for liver) and centrifuged at $10000 \mathrm{~g}$ for $10-20 \mathrm{~min}$ at $4^{\circ} \mathrm{C}$. Supernatants were utilized for the analysis.

Cholinesterase (ChE) activity: $50 \mu \mathrm{l}$ of supernatant or the potassium phosphate buffer (blank) and $200 \mu \mathrm{l}$ of 5,5-dithio-bis-2-nitrobenzoic acid solution $(0.75 \mathrm{mM}$ in potassium phosphate buffer) were added to a 96-well microplate, followed by $50 \mu 1$ of acetylthiocholine iodide solution (54 mM in potassium phosphate buffer) to initiate the reaction (ELLMANN et al., 1961). Absorbance was measured at $415 \mathrm{~nm}$.

EthoxyresorufinO-deethylase

(EROD) activity:EROD was measured in accordance with the method of Burke and Mayer (1974). A volume of 50 $\mu 1$ of supernatant or potassium phosphate buffer (blank) and $420 \mu 1$ of 7-ethoxyresorufin solution (2.6 $\mu \mathrm{M}$ in Tris- $\mathrm{HCl}$ buffer $0.1 \mathrm{M}, \mathrm{pH} 7.5, \mathrm{~T}=27^{\circ} \mathrm{C}$ ) were placed in a quartz cuvette. Reaction was initiated by 
$30 \mu \mathrm{l}$ of $2.6 \mathrm{mM}$ NADPH and resorufin formation was measured in the spectrofluorimeter for $10 \mathrm{~min}$ $($ excitation $=530 \mathrm{~nm}$; emission $=590 \mathrm{~nm})$.

Glutathione S-transferase (GST) activity:50 $\mu l$ of supernatant or potassium phosphate buffer (blank) and $100 \mu$ l of reaction medium (1.5 mM GSH, $2.0 \mathrm{mM}$ CDNB, $0.1 \mathrm{M}$ potassium phosphate buffer, $\mathrm{pH}$ 6.5) were placed in a 96-well microplate. Absorbance increase was immediately measured at $340 \mathrm{~nm}$ for $2 \mathrm{~min}$ at $12 \mathrm{~s}$ intervals and the first interval of 1 min with $r^{2}>0.99$ and the molar extinction coefficient for CDNB of $9.6 \mathrm{mM}^{-1} . \mathrm{cm}^{-1}$ were used to calculate the enzyme activity (KEEN et al., 1976).

Catalase (CAT) activity: $10 \mu \mathrm{l}$ of supernatant or potassium phosphate buffer (blank) was mixed with $990 \mu \mathrm{l}$ of reaction medium $\left(20 \mathrm{mM} \mathrm{H}_{2} \mathrm{O}_{2}\right.$, 50 mMTris-base, $0.25 \mathrm{mM}$ EDTA, $\mathrm{pH} 8.0,25^{\circ} \mathrm{C}$ ) in a quartz cuvette and $\mathrm{H}_{2} \mathrm{O}_{2}$ absorbance decrease was immediately measured at $240 \mathrm{~nm}$ for $1.5 \mathrm{~min}$ at $2 \mathrm{~s}$ intervals. The first $1 \mathrm{~min}$ interval with $\mathrm{r}^{2}>0.99$ and the extinction coefficient for $\mathrm{H}_{2} \mathrm{O}_{2}$ of $40 \mathrm{M}^{-1} \mathrm{~cm}^{-1}$ were used to calculate the enzyme activity (AEBI, 1984).

Protein concentration: total protein concentration was quantified in supernatants and in bile in accordance with Bradford (1976), utilizing bovine serum albumin as standard.

Genetic Procedures

Comet Assay: DNA damage (nonspecific DNA cleavage) was analyzed by means of Comet assay (COLLINS et al., 1997; RAMSDORF et al., 2008). Head kidney samples of fish were homogenized in buffer $(250 \mathrm{mM}$ sucrose, $10 \mathrm{mMtris}$ $\mathrm{HCl}, \mathrm{pH} 8.6$ ), suspended in $0.5 \%$ low-melting point agarose (LMPA), layered onto precoated $1.5 \%$ normal-melting point agarose microscope slides, and spread with a coverslip. After LMPA solidification, the coverslips were removed and the slides were kept in cold-lyses solution $(220 \mathrm{mMNaCl}, 9 \mathrm{mM}$ EDTA, 0.9 mMTris, $1 \%$ Triton $\mathrm{X}-100,10 \%$ DMSO, $0.9 \%$ sodium sarcosianate, $\mathrm{pH} 10$ ) for $24 \mathrm{~h}$ at $4^{\circ} \mathrm{C}$. Then the slides were placed in electrophoresis buffer (300 $\mathrm{mMNaOH}, 1 \mathrm{mM}$ EDTA, 2\% DMSO, $\mathrm{pH}>13$ ) for 20 min to allow DNA unwinding. Electrophoresis was performed at $25 \mathrm{~V}$ and $300 \mathrm{~mA}$ for $25 \mathrm{~min}$. After electrophoresis was completed, the slides were neutralized in $0.4 \mathrm{M}$ Tris- $\mathrm{HCl}(\mathrm{pH} 7.5)$, immersed in absolute ethanol for $10 \mathrm{~min}$ and stained with ethidium bromide $\left(2 \mu \mathrm{g} \mathrm{ml}^{-1}\right)$. All procedures were performed under red light. For analyses, one hundred nuclei per slide were classified according to their tail length $(0,1$, 2, 3 and 4) under the LEICA DMLS2 fluorescence microscope and scored as follows: Score $=\mu$ (damage class $\mathrm{x}$ percentage of incidence).

Micronucleus and Nuclear Abnormalities: blood samples were obtained from the caudal vein of the fish and spread over glass sides. After immersion in ethanol for $30 \mathrm{~min}$, slides were air-dried and stained with $10 \%$ Giemsa solution for 15 min. Small, nonrefractive, circular or ovoid chromatin bodies with the same staining intensity as the nucleus were considered to be micronuclei (AL-SABTI; METCALFE, 1995), whereas nuclear abnormalities were classified in accordance with Carrasco et al. (1990). For statistical purposes, both alterations were counted together in two thousand intact erythrocytes per fish and are referred to hereinafter as nuclear alterations.

\section{Histopathological Procedures}

For morphological investigation, the liver and gills of $A$. brasiliensis were analyzed using a light microscope.

Light microscopy: Gills and liver were fixed in Alfac solution (16 h) and dehydrated in graded series of ethanol and embedded in Paraplast Plus resin $\left(\right.$ Sigma $\left.{ }^{\circledR}\right)$. Sections of $5 \mu \mathrm{m}$ were stained with Haematoxilin and Eosin and observed under the photomicroscope.

\section{Statistical Procedures}

Differences between the collection sites and between seasons were determined independently by means of one-way analysis of variance (ANOVA) followed by the Tukey test for enzymatic parameters and the Kruskal-Wallis test for genetic ones. $P<0.05$ was considered statistically significant.

\section{Results}

Somatic Indexes and Chemical Analyses of Bile

In summer, all the somatic indexes were higher in fish from PIV, the most distant site from the most polluted one, i.e., PI (Fig. 2). The values of the condition factor were generally lower at PII and PIII in the same season. The hepatosomatic index was lower at PI, PII and PIII than at PIV in summer and autumn, but not in winter. Likewise, the gonadsomatic index was lower at those same sites (PI, PII and PIII) in summer and at PII in autumn (Fig. 2).

Comparatively, the concentration of total PAHs in bile in summer was higher in fish from PI, decreasing in individuals from PII and PIII. However, PAH levels were higher in fish from the most distant site (PIV), even though the values were generally being lower than that at PI (Fig. 3). These results were similar to the winter ones, but not to those in autumn; in autumn PII and PIII fish had PAH levels even higher than those at PI, and PII presented a significant increase in PAHs in relation to summer and winter (Fig. 3). 

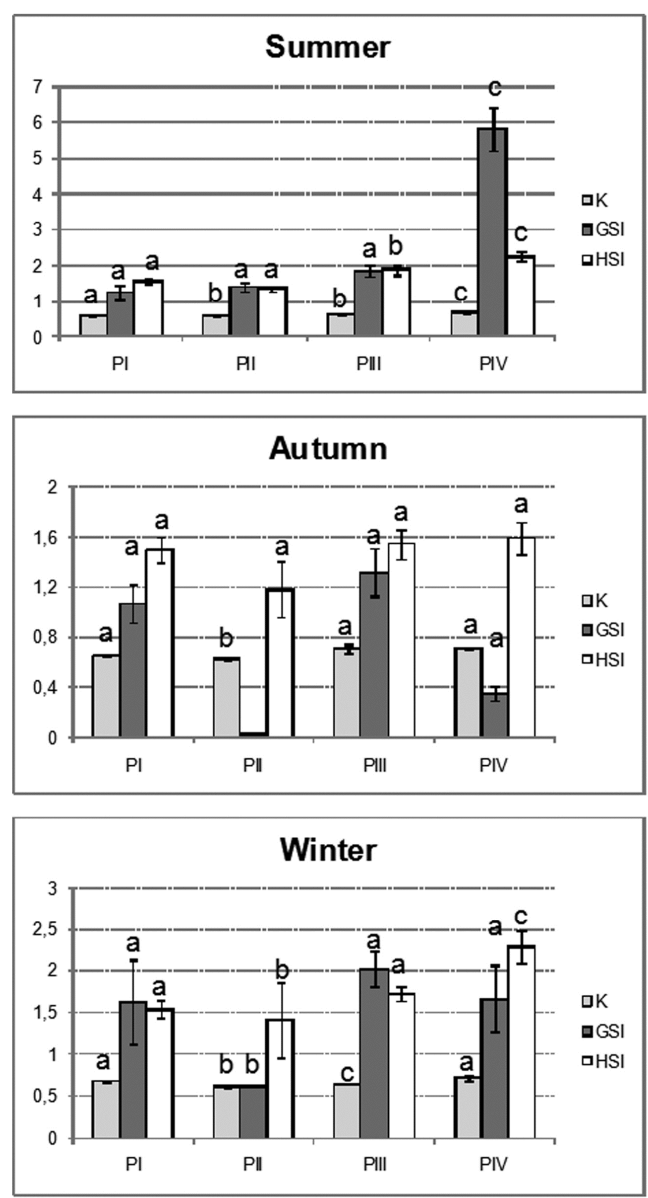

Fig. 2. Comparative values of somatic indexes $(\mathrm{K}-$ condition factor; GSI - gonad-somatic index; HSI hepatosomatic index) in Atherinela brasiliensis captured in summer, autumn and winter. Different letters represent statistically different valuesbetween sampling stations.

Compounds with 2 rings (like naphthalene) were the most abundant in bile for all the study sites and seasons, followed by 3-ring compounds (like phenanthrene) (Fig. 3). Compounds with 4 rings (like pyrene) were present at PI in all the seasons studied and at PII in winter, but they were absent at PIII in all the seasons. In fish captured at PIV site, compounds with 4 rings were present only in summer (Fig. 3).

Biochemical Biomarkers

GST activity was similar in fish at the various sampling sites and in all the seasons (data not shown). Fish from PII, PIII and PIV had the lowest hepatic EROD activities in summer, but no differences between sites were observed within any particular season (Fig. 4). For PI site, EROD activity was similar in all seasons (Fig. 4). Muscle $\mathrm{ChE}$ activity values varied between seasons in PI, PII and PIII, and at these sites enzyme activities were lower in fish captured in summer and winter than in autumn (Fig.5). Muscle of fish from PIV presented the lowest $\mathrm{ChE}$ activity compared with those of other sites in summer and autumn. In autumn, however, ChE was highest at PII (Fig. 4). Fish from different sites had similar hepatic catalase activity in summer, but lower activity was observed in those from PII and PIII in winter; and from PII and PIV in autumn. Also, in winter fish from PIV had higher catalase activity than those from PII and PIII but not in those from PI (Fig. 6). Seasonal differences occurred for catalase at PII, the highest activity being recorded during summer and at PIV with the lowest activity during autumn (Fig. 4).

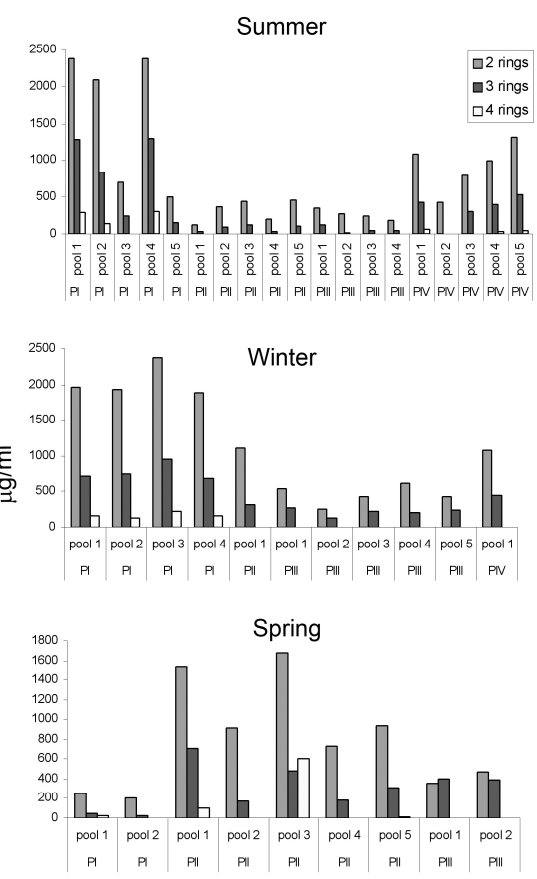

Fig. 3. PAHs in bile of Atherinela brasiliensis from stuły sites PI, PII, PIII and PIV captured during summer (I), winter (II) and autumn (III). 2 rings (naphthalene type), 3 rings (phenanthrene type) and 4 rings (pyrene type). Each pool represents 2-5 individuals.

\section{Genetic Parameters}

Comet and nuclear alteration analyses were performed only in the fish from three sites (PI, PII and PIV) collected in winter. Fish from PIV had lower levels of DNA damage and nuclear alterations than did those from PI and PII. These two latter sites had similar levels of nuclear alterations, but DNA damage was greater at PII than at PI (Table 1). 

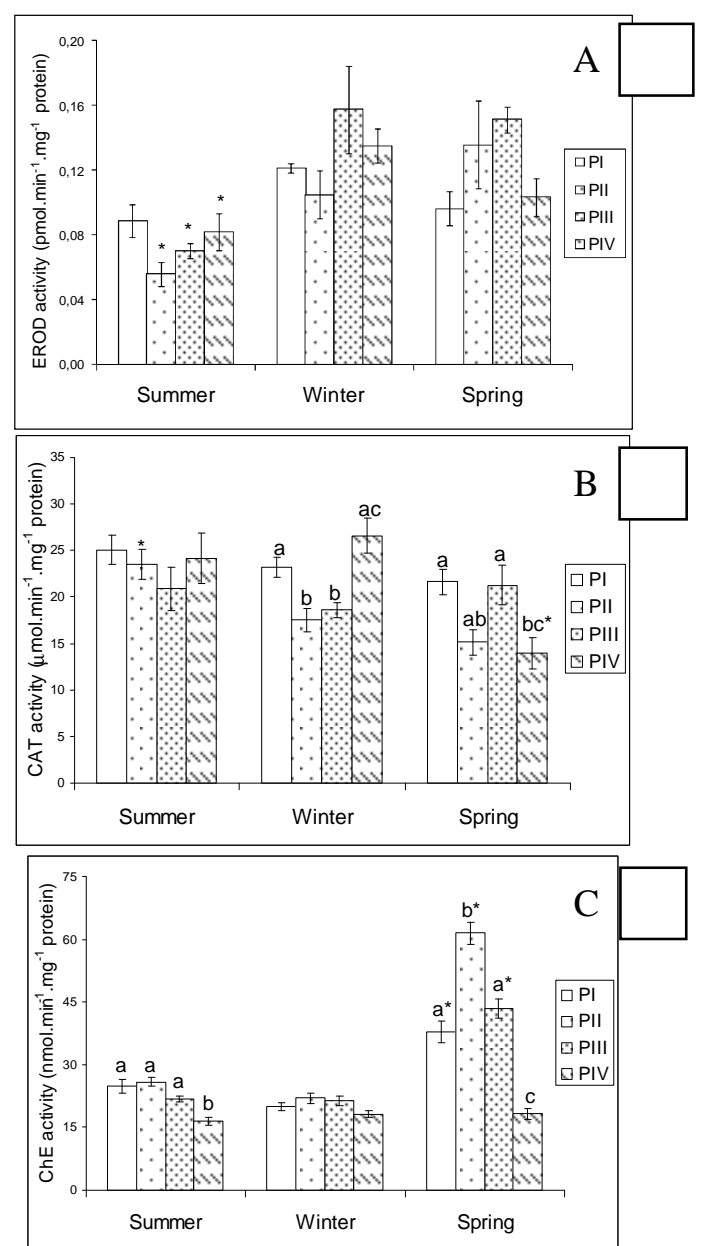

Fig. 4 A. - EROD. B - Catalase activity in liver. C ChE activity of the muscle of Atherinela brasiliensis from sites PI, PII, PIII and PIV captured during summer, winter and autumn. Different letters indicate statistically different activities between the sites but within the same season. Asterisks indicate differences at the same site but in different seasons.

Histopathological Parameters

Table 2 presents the morphological alterations observed in fish liver and gills.
Fish captured at PI and PII showed higher incidences of neoplasia at the base and the extremity of the secondary lamellae (Fig. 5). Aneurysms (Fig. $5 \mathrm{~A})$ were found in the majority of individuals from all the sites studied. Necrosis was the most abundant injury observed in liver of the majority of the fish from all the sites (Fig. 6 and Table 2). Cytoplasm steatosis in hepatocytes was observed in fish from all sites (Fig. 6 and Table 2), indicating an apparent disturbance in cellular metabolism. Another type of steatosis was characterized by the concentration of small bodies or 'vesicles' that may result from increased secretion rates (Fig. 6). The presence of invasive and non-invasive neoplasia (Fig. 7) was indicative of chronic and hazardous damage in the liver of A. brasiliensis from all studied sites (Table 2). The presence of hepatic parasites in fish from all the study sites was a strong indication of immunodepression (Fig. 8).

\section{DisCUSSION}

Somatic indexes may provide practical parameters to evaluate fish's health conditions. For $A$. brasiliensis, the high somatic index values in summer for PIV were associated with nutrient and food enrichment resulting from urban discharge and the apparently least intense presence of pollutants due to the site's being situated at the greatest distance from the most severely impacted site (PI). Although PI was also impacted by urban discharge, the comparatively lower values of somatic indexes in summer for PI, PII and PIII demonstrated that the presence of other pollutants interfered with the health conditions of rganisms. A similar pattern was found in autumn, but $\mathrm{n}$ winter the values were lower and more Iomogeneous at all the study sites. This finding can be :xplained by the lowest remobilization and dynamic of ediments during winter due to the low rainfall. In ,eneral, somatic index values increased as the study ites receded from PI and approached the open ocean. $I^{7}$ urther, a seasonal effect was detected for individuals collected during the summer, as they were more greatly affected than those collected during winter and autumn.

Table 3.Occurrence of morphological lesions in liver of Atherinella brasiliensis from Paranaguá estuary after Vicuña ship accident.

\begin{tabular}{llllcccc}
\hline \hline \hline \multirow{5}{*}{ Summer } & CMM & LI & Neoplasia & Necrosis & Vacuolization & Parasites \\
& P I & $10(10)$ & $2(10)$ & $3(10)$ & $3(10)$ & $2(10)$ & $10(10)$ \\
& P II & $8(10)$ & $0(10)$ & $4(10)$ & $5(10)$ & $3(10)$ & $6(10)$ \\
& P III & $6(10)$ & $0(10)$ & $2(10)$ & $7(10)$ & $5(10)$ & $8(10)$ \\
\multirow{5}{*}{ Winter } & P IV & $4(10)$ & $2(10)$ & $2(10)$ & $4(10)$ & $4(10)$ & $0(10)$ \\
& P I & $4(10)$ & $2(10)$ & $0(10)$ & $6(10)$ & $4(10)$ & $5(10)$ \\
& P II & $2(10)$ & $0(10)$ & $2(10)$ & $3(10)$ & $5(10)$ & $1(10)$ \\
& P III & $5(10)$ & $1(10)$ & $3(10)$ & $6(10)$ & $6(10)$ & $10(10)$ \\
Spring & P IV & $3(10)$ & $0(10)$ & $2(10)$ & $0(10)$ & $5(10)$ & $2(10)$ \\
& P I & $6(10)$ & $1(10)$ & $2(10)$ & $9(10)$ & $5(10)$ & $6(10)$ \\
& P II & $1(10)$ & $0(10)$ & $2(10)$ & $5(10)$ & $4(10)$ & $4(10)$ \\
& P III & $4(10)$ & $0(10)$ & $0(10)$ & $5(10)$ & $4(10)$ & $7(10)$ \\
\hline
\end{tabular}

CMM = Melanomacrophage Center, $\mathrm{LI}=$ Leukocytes infiltration, ( ) number of individuals 


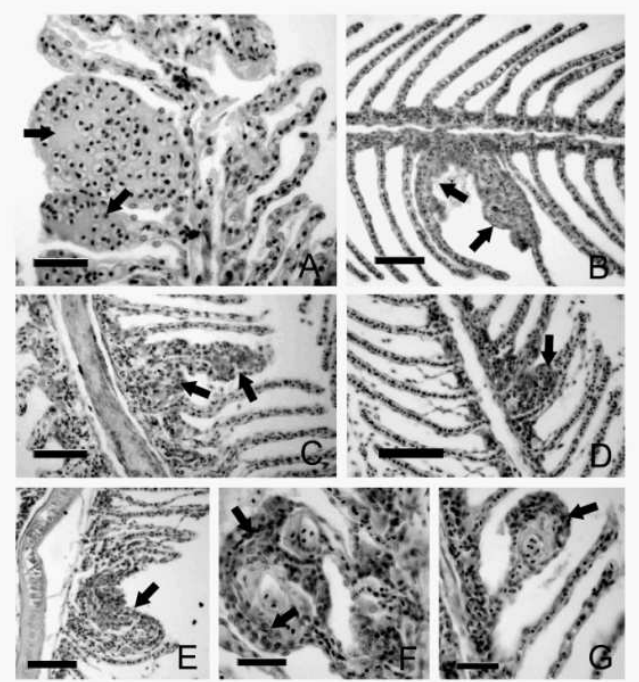

Fig. 5. Gills of Atherinela brasiliensis from Paranaguá Bay stained with Haematoxilin and Eosin. A Aneurisms (arrow). B, C, D, E - cell proliferation and fusion of secondary lamellae (arrows). F, G - cell proliferation in secondary lamellae extremity (arrows, bar $=50 \mu \mathrm{m})$. Bars: A, F, G = $50 \mu \mathrm{m} ; \mathrm{B}, \mathrm{C}, \mathrm{D}, \mathrm{E}=100$ $\mu \mathrm{m}$.

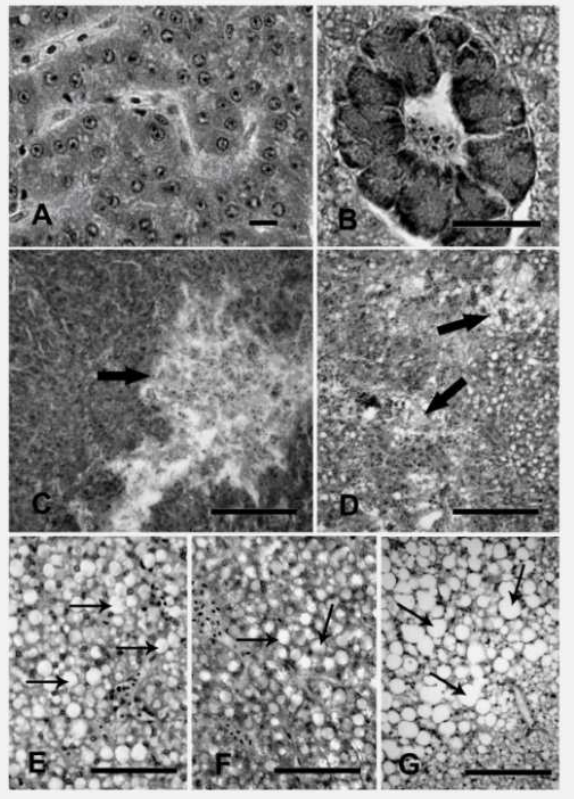

Fig.6. Liver of Atherinela brasiliensis from Paranaguá Bay stained with Haematoxilin and Eosin. A - tissue without lesion. B - pancreatic tissue island in liver (bar = $50 \mu \mathrm{m})$. C, D - large necrotic areas (arrows). E, F, G different aspects of steatosis (arrows). Bars: $A=10 \mu \mathrm{m}$; $\mathrm{B}=50 \mu \mathrm{m} ; \mathrm{C}, \mathrm{D}, \mathrm{E}, \mathrm{F}$ and $\mathrm{G}=100 \mu \mathrm{m}$.

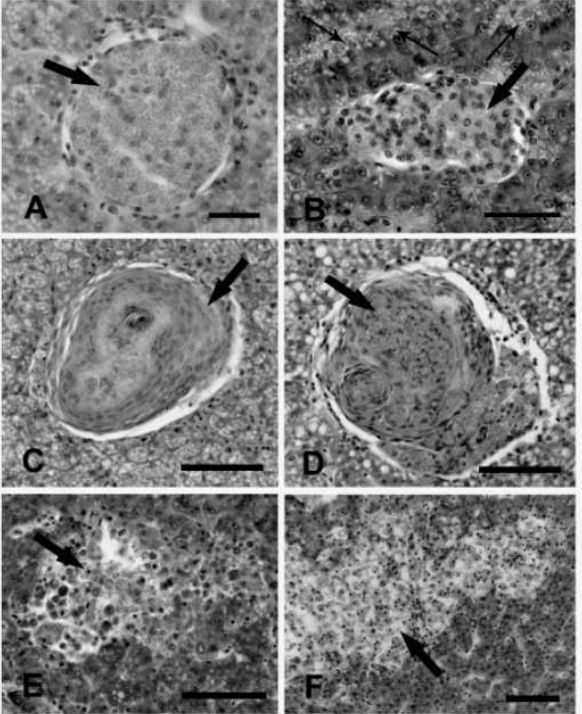

Fig. 7.Neoplasia in liver of Atherinela brasiliensis from Paranaguá Bay stained with Haematoxilin and Eosin. A, B, C, D - distinct encapsulated neoplasia (arrows). In B the small arrows point to vesicles in the hepatocytes. E, $\mathrm{F}$ - invasive neoplasia (arrows). Bars: $\mathrm{A}=20 \mu \mathrm{m} ; \mathrm{B}=$ $100 \mu \mathrm{m} ; \mathrm{C}, \mathrm{D}$ and $\mathrm{E}=50 \mu \mathrm{m} ; \mathrm{F}=100 \mu \mathrm{m}$.

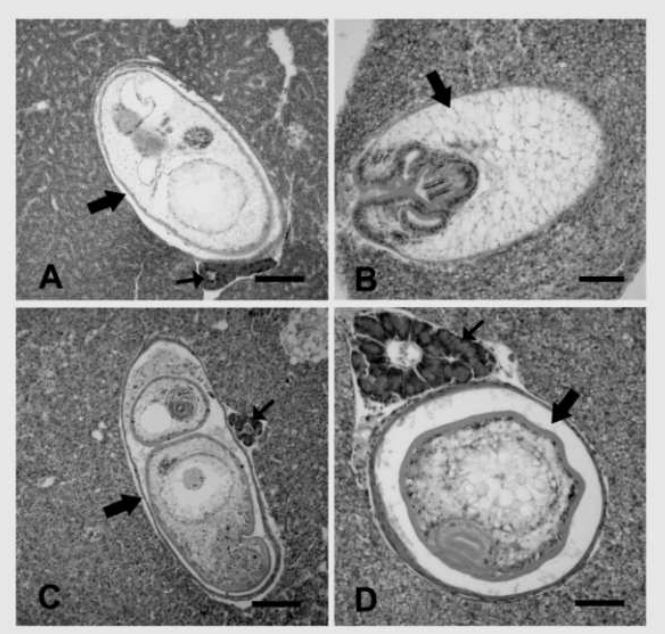

Fig. 8. Parasites in the liver of Atherinela brasiliensis from Paranaguá Bay stained with Haematoxilin and Eosin. Large arrows point to the parasites and small arrows point to the pancreatic tissue. $\mathrm{Bar}=100 \mu \mathrm{m}$.

Particularly, the lower GSI level found Iring summer at the sites closest to the area of the cident may result in decreased fecundity caused by oavailable pollutants. For HSI, although it can be 
positively associated with PAHs (PINKNEY et al., 2001), no such association was observed either by this present study or by another (YANG; BAUMANN, 2006). Interactions between the various contaminants, such as metals, present in the Paranaguá estuary (HOQUE et al., 1998)may be responsible for the weak negative association between HSI and the biliary PAHs also described by YANG; BAUMANN (2006).

The fluorimetric data on the bile showed the involvement of the harbor activities and probably the Vicuña accident with PAH bioavailability, resulting in high biliary PAH values during summer and decreased values during winter and autumn. Pyrene type compounds have been the major hydrocarbon found in the bile of several fish species (PIKKARAINEN, 2006; RUDDOCK et al., 2002), though not in $A$. brasiliensis. These compounds were present in fish from PI, but not in those from PIII. Their presence also in fish from PIV, the closest site to Pontal do Parana city, corroborated the idea that the accident and the harbor activities together contributed to $\mathrm{PAH}$ bioavailability.

The decreased activity of ChE at PIV revealed a continuous impairment of $\mathrm{ChE}$ by pollutants released from urban areas and the harbor of Pontal do Sul city. Not least, the worst situation for ChE seemed to arise during summer and winter rather than in the autumn. The exact reason for this particular result and for EROD seasonal differences requires further investigation, but sediment dynamics and pollutant remobilization may be involved. $\mathrm{ChE}$ activity is a valuable biomarker in biomonitoring programs (OLIVEIRA RIBEIRO; SILVA DE ASSIS, 2005a) and its inhibition by PAHs (AKAISHI et al., 2004) and other pollutants has important consequences for the swimming, behavior, feeding and survival of fish. Likewise, the induction of EROD is a sensitive response to exposure to various anthropogenic chemicals (OLIVEIRA RIBEIRO et al., 2005b; STEGEMAN; HAHN, 1994), although the absence of any correlation between EROD activity and PAHs has already been reported for fish (AAS; KUNGSOYR, 1998).

ChE, EROD and GST activities did not emphasize the pollution gradient assumed to exist at the beginning of our investigation. In particular, GST activity has not been altered by any possible comparison, even though it has already proved its suitability to verifying the effects of pollutants elsewhere (FILIPAK NETO et al., 2007; SIMONATO et al., 2008; WANG et al., 2006). CAT, on the other hand, weakly indicated a pollution gradient in winter, when fish from PII and PIII presented inhibited activityas compared with those from PIV. All these observations indicate that the long-term exposure to and presence of other pollutants may be interfering with the enzymatic biomarkers, leading to responses that do not correlate completely with site and seasonal differences in PAH levels.

The highest incidence of DNA damage in the cells of fish from PII and the decreasing levels of nuclear alterations from PI toward the PIV site indicated the presence of a gradient of pollutants with genotoxic properties. As with the other parameters, PAH bioavailability as well as the presence of other pollutants may be responsible for the findings, since many chemicals including PAHs and metals have genotoxic properties. Extensive DNA damage in kidney cells certainly threatens fish's health. The kidney has hematopoietic functions in fish and cell damage as well as peripheral erythrocytes' nuclei have provided fundamental information about acute and chronic exposure to genotoxic pollutants in Paranaguá estuary.

The alteration of gill architecture due to cell proliferation, lamellar fusion and aneurisms was consistent with the data reported for organic pollutants (AKAISHI et al., 2004; OLIVEIRA RIBEIRO et al., 2005b) and resulted from the deleterious effects of pollutants rather than compensatory responses. These injuries compromise gill function and consequently can result in susceptibility to other pathological conditions, including infection by opportunist organisms.

Likewise, liver function can be compromised by pollutants and so a number of adverse consequences for growth, health and reproduction of organisms can arise, affecting even natural populations. But, better than gills, liver registers chronic exposure in the form of hepatic lesions. Liver lesions have been diagnosed in various fish species on the basis of internationally accepted diagnostic criteria (MIRANDA et al., 2008; VIARENGO et al., 2007), which we have utilized. Several alterations, including necrotic and neoplasic areas and leukocyte infiltration have been identified in the liver of A. brasiliensis, indicating health problems, though not a pollution gradient.

Necrosis is a degenerative lesion characterized by cell lysis followed by tissue disorganization. Metals (Melee al., 2007), PAHs (OLIVEIRA RIBEIRO et al., 2005b) and PCBs (MIRANDA et al., 2008) can cause necrosis. Thus the high incidence of necrosis observed in A. brasiliensis probably resulted from a continuous, multiple and varied exposure to pollutants.

Abnormal lipid accumulation (steatosis) could be responsible for the cytosolic vacuolization observed in hepatocytes of $A$. brasiliensis as reported elsewhere in fish that had PAH residues in bile (MARTY et al., 2003), fish exposed to hydrophobic pollutants such as polychlorinated biphenyls, organochlorine pesticides and PAHs (OLIVEIRA 
RIBEIRO et al., 2005b) or in fish caught in the area of the Exxon Valdez oil spill (MARTY et al., 2003).

Although hepatic necrosis and steatosis have harmful consequences for organisms, their progression usually depends on continuous exposure to the chemicals concerned, i.e., when the insult ceases the lesion is healed or stops progressing if the fish survive. Chronic exposure to PAHs and many other pollutants, however, can cause neoplasia and once these tumors are present they can potentially progress to cancer even without additional or continued insults. Liver microscopy provided some evidence of a connection between human activities and the Vicuña accident in the Paranaguá estuary and the incidence of hepatic neoplasia, since fish from PI and PII had more lesions than those from PIII and PIV during summer and autumn. However, the carcinogenic potential of different PAHs and isomers varies greatly (e.g., the five-ring carcinogenic benzo[a]pyrene but not carcinogenic benzo[e]pyrene, Carrel et al., 1997), so that the fluorometric analyses undertaken in the present study did not have the resolution required for any better assumption than the existence of a rough connection between biliary PAH levels and the incidence of neoplasia. This limitation, however, does not diminish the significance of the striking observation that the very high incidence of neoplasia in A. brasiliensis reflects the unhealthy status of the Paranaguá estuary. This idea was reinforced by the genetic parameters previously discussed, and the presence of hepatic parasites. Similar data had already been reported by Marigómez et al (2006) for the liver and Oliveira Ribeiro et al (2005b) for the gills of fish and the presence of parasites seems thus tobe a very good parameter for the verification of the health status of aquatic organisms.

\section{Conclusions}

As already reported by Katsumiti et al. (2009), the harbor is an important source of contamination in the Paranaguá estuary, to which the Vicuña accident contributed, but further study is required to assess the real risk to humans and other species. Overall, the pollution gradient from Paranaguá harbor toward the open ocean was weakly corroborated by the presence of PAHs in bile, somatic indexes, CAT activity and the genetic parameters, so that Pontal do Parana city may be considered as already having been impacted by hazardous pollutants although on a minor scale. The histopathological data revealed the most striking, cumulative and concerning findings: A. brasiliensis collected at the four sites presented hazardous injuries to their liver and gills, indicating that these fish are at serious risk. It is important to bear in mind that Paranaguá bay has three protected areas listed by UNESCO.

\section{ACKNOWLEDGEMENTS}

The current study was supported by $\mathrm{CNPq}$ (Brazilian Agency for Science and Technology) and CNRS (Centre National de la Recherche ScientifiqueFrance). The authors thank the Ocean Studies Center of the Federal University of Parana for their technical assistance and collection facilities.

\section{REFERENCES}

AAS, E.; KLUGSOYR, J. PAH metabolites in bile and EROD activity in North Sea Fish. Mar. Environ Res., v. 46, n.1-5, p. 229-232, 1998.

AAS, E.; BEYER, I.; GOKSOYR, A. Fixed wavelength fluorescence (FF) of bile as a monitoring tool for polyaromatic hydrocarbon exposure in fish: an evaluation of compound specificity, inner filter effect and signal interpretation. Biomarkers, v. 5, p. 9-23, 2000.

AEBI, H. Catalase in vitro. Meth. Enzymol., v. 105, p. 121$126,1984$.

AKAISHI, F.M.; SILVA DE ASSIS, H. C.; JAKOBI, S. S. G.; EIRAS-STOFELLA, D. R.; ST-JEAN, S. D.; COURTENAY, S. C.; LIMA, E. F.; WAGENER, A. L. R.; SCOFIELD, A. L.; OLIVEIRA RIBEIRO, C. A. Morphological and neurotoxicological findings in tropical freshwater fish (Astyanax sp.) after waterborne and acute exposure to water soluble fraction (wsf) of crude oil. Arch. Environ. Con. Tox.., v. 46, p. 244-253, 2004.

AKAISHI, F. M.; ST-JEAN, S. D.; BISHAY, F.; CLARKE, J.; RABITTO, I.S.; OLIVEIRA RIBEIRO, C.A. Immunological responses, histopathological finding and disease resistance of blue mussel (Mytilus edulis) exposed to treated and untreated municipal wastewater. Aquat. Toxicol. v. 82, p. 1-14, 2007.

ALBERTO, A.; CAMARGO, A. D. M.; VERANI, J. R.; COSTA, O. F. T.; FERNANDES, M. N. Heath variables and gill morphology in the tropical fish Astyanax fasciatus from a sewage contaminated river. Ecotox. Environ. Saf., v. 61, p. 247-255, 2005.

AL-SABTI, K.; METCALFE, C. D. Fish micronuclei for assessing genotoxicity in water. Mutat. Res., v. 343, p. 121-135, 1995.

ALVES COSTA, J. R. M.; MELA, M.; SILVA DE ASSIS, H. C.; PELLETIER, E.; RANDI, M. A. F.; OLIVEIRA RIBEIRO, C. A. Enzymatic inhibition and morphological changes in Hoplias malabaricus from dietary exposure to lead (II) or methylmercury. Ecotox. Environ. Saf., v. 67, p. 82-88, 2007.

ANDRIGHETTI-FRÖHNER, C. R.; KRATZ, J. M.; ANTONIO, R. V.; CRECZYNSKI-PASA, T. B.; BARARDI, C. R. M.; SIMÕES, C. M. O. In vitro testing for genotoxicity of violacein assessed by Comet and Micronucleus assays. Mutat. Res., v.603, p. 97-103, 2006.

BRADFORD, M. A rapid and sensitive method for the quantitation of microgram quantities of protein utilizing the principle of protein dye binding. Ann. Bioch., v. 72, p. 248-254, 1976. 
BURKE, M. D.; MAYER, R. T. Ethoxyresorufin: direct fluorimetric assay of a microssomal O-dealkylation which is preferentially inducible by 3-methylcholantrene. Drug Metabol. Dispos., v. 2, p. 583-588, 1974.

CARRASCO, K. R.; TILBURY, K. L.; MYERS, M .S. Assessment of the piscine micronucleus test as in situ biological indicator of chemical contaminant effects. Can. J. Fish Aquat. Sci., v. 47, p. 2123-2136, 1990.

CARRELL, C. J.; CARRELL, T. G.; CARRELL, H. L.; PROUT, K.; GLUSKE, J.P. Benzo[a]pyrene and its analogues: structural studies of molecular strain. Carcinogenesis, v. 18, n. 2, p. 415-422, 1997.

COLLINS, A.; DUSINSKÁ, M.; FRANKLIN, M.; PETROVSKÁ, H.; DUTHIE, S.; FILLION, L.; PANAYIOTIDIS, M.; RASLOVÁ, K.; VAUGHAN, N. Comet assay in human biomonitoring studies: reliability, validation, and applications. Environ. Mol. Mutagen., v. 30, n. 2 , p. $139-146,1997$

DAMÁSIO, J. B.; BARATA, C.; MUNNÉ, A.; GINEBREDA, A.; GUASCH, H.; SABATER, S.; CAIXACH, J.; PORTE, C. Comparing the response of biochemical indicators (biomarkers) and biological indices to diagnose the ecological impact of an oil spillage in a Mediterranean river (NE Catalunya, Spain). Chemosphere, v. 66, n. 7, p. 1206-1216, 2007.

ELLMANN, G. L.; COURTNEY, K. O.; ANDRRES, V. FEATHERSTONE, R. M. A new and rapid colorimetric determination of acetylcholinesterase activity. Biochem. Pharmacol., v. 7, p. 88-95, 1961.

FILIPAK NETO, F.; ZANATA, S. M.; SILVA DE ASSIS, H.C.; BUSSOLARO, D.; FERRARO, M. V. M.; RANDI, M. A. F.; ALVES COSTA, J. R. M.; CESTARI, M. M.; ROCHE, H.; OLIVEIRA RIBEIRO, C. A. Use of hepatocytes from Hoplias malabaricusto characterize the toxicity of a complex mixture of lipophilic halogenated compounds. Toxicol. In Vitro, v. 21, p. 706-715, 2007.

HELCOM. Manual formarine monitoring in the COMBINE Programme of HELCOM, http://sea.helcom.fi/Monas/CombineManual2/CombineHome.htm, 2006

HOQUE, M. T.; YUSOFF, F. M. Law A.; SYED, M. A. Effect of hydrogen sulphide on liver-somatic index and Fulton's condition factor in Mystus nemurus. J. Fish Biol., v. 52, p. 23-30, 1998.

ICES. Report of the Advisory Committee on the Marine Environment. ICES Cooperative Research Report, 2001. v. 248, p. 203.

KATSUMITI, A.; VALDEZ DOMINGOS, F.X.; AZEVEDO, M.; DA SILVA, M. D.; DAMIAN, R. C.; ALMEIDA, M. I. M.; SILVA DE ASSIS, H. C.; CESTARI, M.M.; RANDI, M. A. F.; OLIVEIRA RIBEIRO, C. A.; FREIRE, C. A. An assessment of acute biomarker responses in the demersal catfish Cathorops spixii after the Vicuña Oil Spill in a harbour estuarine area in Southern Brazil. Environ Monit. Assess, v. 152, p. 209-222, 2009

KEEN, J. H.; HABIG, W.; JAKOBY, W. B. Mecanism for several activities of the glutatione S-transferase, J. Biol. Chem., v. 251, p.6183-6188, 1976.

LYONS, B. P.; STENTIFORD, G. D.; BIGNELL, J.; GOODSIR, F.; SIVYER, D. B.; DEVLIN, M. J.; LOWE, D.; BEESLEY, A.; PASCOE, C. K.; MOORE, M. N.; GARNACHO, E. Biological effects monitoring survey of Cardigan bay using flatfish histopathology, Cellular biomarkers and Sediment bioassays: findings of the prince madog prize. Mar. Environ. Res., v. 62, p. 342346, 2006.

MARIGÓMEZ, I.; SOTO, M.; CANCIO, I.; ORBEA, A.; GARMENDIA, L.; CAJARAVILLE, M. P. Cell and tissue biomarkers in mussel, and histopathology in hake and anchovy from Bay of Biscay after the Prestige oil spill (Monitoring Campaign 2003). Mar. Pollut. Bull., v. 53, p. 287-304, 2006.

MARTY, G. D.; HOFFMANN, A.; OKIHIRO, M. S.; HEPLER, K.; HANES, D. Retrospective analyses: bile hydrocarbons and histopathology of demersal rockfish in Prince William sound, Alaska, after the Exxon Valdez oil spill. Mar. Environ. Res., v. 56, p. 569-584, 2003.

MELA, M.; RANDI, M. A. F.; VENTURA, D. F.; CARVALHO, C. E. V.; PELlETIER, E.; OLIVEIRA RIBEIRO, C. A. Effects of dietary methylmercury on liver and kidney histology in the neotropical fish Hoplias malabaricus. Ecotox. Environ. Saf., v. 68, p. 426-435, 2007.

MIRANDA, A. L.; ROCHE, H.; RANDI, M. A. F.; MENEZES, M. L.; OLIVEIRA RIBEIRO, C. A. Bioaccumulation of chlorinated pesticides and PCBs in the tropical freshwater fish Hoplias malabaricus: Histopathological, physiological, and immunological findings. Environ. Int., v. 34, p. 939-949, 2008.

OLIVEIRA RIBEIRO C. A; SILVA DE ASSIS, H. C. AChE inhibition as a Biomarker for pollutants contamination in tropical aquatic ecossistems. In: MAHIRA PARVEEN; SANTOSH KUMAR.(Org.). Recent trendsin Acetylcholinesterase. Amsterdam: IOS Press, 2005a.p .103-124.

OLIVEIRA RIBEIRO, C. A.; VOLLAIRE, Y.; SANCHEZCHARDI, A.; ROCHE, H. Bioaccumulation and the effects of organochlorine pesticides, $\mathrm{PAH}$ and heavy metals in the Eel (Anguilla anguilla) at the Camargue Nature Reserve, France. Aquat. Toxicol., v. 74, p. 5369, $2005 \mathrm{~b}$.

PIKKARAINEN, A. Ethoxyresorufin-O-deethylase (EROD) activity and bile metabolites as contamination indicators in Baltic Sea perch: Determination by HPLC. Chemosphere, v. 65, p. 1888-1897, 2006.

PINKNEY, A. E.; HARSHBARGER, J. C.; MAY, E. B.; MELANCON, M. J. Tumor prevalence and biomarkers of exposure in brown bullheads (Ameiurus nebulosus) from the tidal Potomac River, USA, Watershed. Environ. Toxicol. Chem., v. 20, p. 1196-1205, 2001.

RABITTO, I. S.; BASTOS, W. R.; ALMEIDA, R.; ANJOS, A.; DE HOLANDA, I. B. B.; GALVÃO, R. C. F.; FILIPAK NETO, F.; MENEZES, M.L.; SANTOS, C.A.M.; OLIVEIRA RIBEIRO, C.A. Mercury and DDT exposurerisktofish-eatinghuman populations in Amazon. Environ. Int., v. 37, p. 56-65, 2011.

RAMSDORF, W. A.; FERRARO, M. V. M.; OLIVEIRA RIBEIRO, C. A.; ALVES COSTA, J. R. M.; CESTARI, M. M. Genotoxic evaluation of different doses of inorganic lead (PbII) in Hoplias malabaricus. Environ. Monit. Assess., v. 158, n. 1-4, p. 77-85, 2008.

RUDDOCK, P. J.; BIRD, D. J.; MCCALLEY, D. V. Bile metabolites of polycyclic aromatic hydrocarbons in three species of fish from the Severn Estuary. Ecotox. Environ. Saf., v. 39, p. 147-153, 2002. 
SILVA, A. G.; MARTINEZ, C. B. R. Morphological changes in the kidney of a fish living in an urban stream. Environ. Toxicol. Pharmacol., v. 23, p. 185-192, 2007.

SILVA, C. A.; OLIVEIRA RIBEIRO, C. A.; KATSUMITI, A.; ARAÚJO, M. L. P.; ZANDONÁ, E. M.; COSTA SILVA, G. P.; MASCHIO, J; ROCHE, H.; SILVA DE ASSIS, H. C. Evaluation of waterborne exposure to oil spill 5 years after an accident in Southern Brazil. Ecotox. Environ. Saf., v. 72, p. 400-409, 2009.

SILVA, C. A.; OBA, E. T.; RAMSDORF, W. A.; MAGALHÃES, V. F.; CESTARI, M. M.; OLIVEIRA RIBEIRO, C. A.; SILVA DE ASSIS, H. C. First report about saxitoxins in freshwater fish Hoplias malabaricus through trophic exposure. Toxicon, v. 57, p. 141-147, 2011

SIMONATO, J. D.; GUEDES, C. L. B.; MARTINEZ, C. B. R. Biochemical, physiological, and histological changes in the neotropical fish Prochilodus lineatus exposed to diesel oil. Ecotoxicol. Environ. Saf., v. 69, p. 112-120, 2008.

STEGEMAN, J. J.; HAHN, M. E. Biochemistry and Molecular Biology of Monooxigenases: current perspectives on forms, functions and regulation of cytochrome $\mathrm{P} 450$ in aquatic species. In: Aquatic Toxicology: Molecular, Biochemical and Cellular Perspectives. ed. Ostrander, G. K.; D. Malins, D. (Ed.) Boca Raton, Fl.: Lewis Publishers, 1994.612p.

TEJEDA-VERA, R.; LOPEZ-LOPEZ, E.; SEDENO-DIAZ, J. E. Biomarkers and bioindicators of the health condition of Ameca splendens and Goodea atripinnis (Pisces: Goodeaidae) in the Ameca River, México. Environ. Internat., v. 33, p. 521-531, 2008.

UNEP: MED POL - Phase III Program for the assessment and control of pollution in the Mediterranean region. MAP Technical Reports Series No. 120, Athens: UNEP, 1999. MAP Technical Reports Series, n. 120.
VANPARYS, C.; DAUWE, T.; VAN CAMPENHOUT, K.; BERVOETS, L.; DE COEN, W.; BLUST, R.; MARCEL, E. Metallothioneins (MTs) and $\delta$ aminolevulinic acid dehydratase (ALAd) as biomarkers of metal pollution in great tits (Parus major) along a pollution gradient. Sci. Total. Environ., v. 40, n. 1-3, p. 184-193, 2008

VIARENGO, A.; LOWE, D.; BOLOGNESI, C.; FABBRI, E.; KOEHLER, A. The use of biomarkers in biomonitoring: A 2-tier approach assessing the level of pollutant-induced stress syndrome in sentinel organism. Comp. Biochem. Physiol. Part C., v. 146, p. 281-300, 2007.

WANG, C. G.; ZHAO, Y.; ZHENG, R. H. Effects of tributyltin, benzo[a]pyrene, and their mixture on antioxidant defense systems in Sebastiscus marmoratus. Ecotoxicol. Environ. Saf., v. 65, p. 381-387, 2006.

YANG, X.; BAUMANN, P. C. Biliary PAH metabolites and the hepatosomatic index of brown bullheads from Lake Erie tributaries. Ecol. Indic., v. 6, p. 567-574, 2006.

(Manuscript received 14 April 2011; revised 29 November 2012; accepted 17 January 2013) 